\title{
Mobile Game for Equality of Fractions for Elementary School Students
}

\section{Ayu Wulandari' ${ }^{1}$ Mohammad Faizal Amir ${ }^{2 *}$}

\author{
1,2 Elementary School Teacher Education Department, Universitas Muhammadiyah Sidoarjo, Indonesia
}

\section{ART ICLE INF O}

Article history:

Received October 02, 2021

Revised October 04, 2021

Accepted November 14, 202

Available online November 25, 2021

Kata Kunci:

Hasil Belajar, Pecahan Senilai, Teknologi Mobile

Keywords:

Equalityof Fraction, Learning Outcomes, Mobile Technology

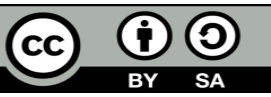

This is an open access article under the CC BY-SA license.

Copyright (C) 2021 by Author. Published by Universitas Pendidikan Ganesha.

\begin{abstract}
A B S T R A K
Rendahnya hasil belajar pada materi pecahan senilai disebabkan karena ketidaktersediaan media game teknologi mobile yang dapat melatihkan dan mendalami pola pecahan senilai secara tepat. Penelitian ini bertujuan untuk menghasilkan mobile game for equality of fractions (MoGEF) yang valid, praktis dan efektif untuk meningkatkan hasil belajar pada materi pecahan senilai. Penelitian ini menggunakan metode research and development melalui analisis, desain, pengembangan, implemenasi, dan evaluasi. Subjek penelitian ini siswa kelas 4 sekolah dasar sebanyak 29 siswa. Kevalidan diukur melalui penilaian dua ahli (ahli pendidikan matematika dan ahli pendidikan teknologi informasi). Kepraktisan diukur melalui hasil kuisioner respon siswa. Keefektifan diukur melalui posttest hasil belajar siswa setelah menggunakan MoGEF. Teknik pengumpulan data menggunakan kuisioner dan tes. Hasil validitas diperoleh rata - rata $86.06 \%$ yang berada pada interval $85.00 \%<V \leq 100.00 \%$ dengan kriteria sangat valid. Kepraktisan diperoleh rata - rata sebesar 4.659 yang berada pada interval $2.50<$ $V \leq 3.25$ dengan kriteria sangat praktis. Efektivitas diperoleh rata - rata sebesar $79.83 \%$ berada pada interval $70.00 \%<V \leq 85.00 \%$ dengan kriteria efektif. Efektifitas mobile game diperoleh nilai signifikansi 2.127 > 2.048 yang berarti dapat meningkatkan hasil belajar siswa sekolah dasar pada materi pecahan senilai. Oleh karenanya, pengembangan mobile game for equality of fraction disimpulkan sangat valid, sangat praktis dan efektif.
\end{abstract}

\begin{abstract}
A B S T R A C T
The low learning outcomes in the equality of fractions material are due to the unavailability of mobile technology game media that can train and explore the pattern of equality of fractions appropriately. This study aims to produce a valid, practical, and effective mobile game for equality of fractions (MoGEF) to improve learning outcomes on equality of fractions material. This study uses research and development methods through analysis, design, development, implementation, and evaluation. The subjects of this study were 29 students in the fourth grade of elementary school. Validity was measured by assessing two experts (mathematical education expert and information technology education expert). Practicality was measured through the results of the student response questionnaire, while effectiveness was measured through the posttest of student learning outcomes after using MoGEF. Data were collected using questionnaires and tests. The validity results obtained an average of $86.06 \%$ in the interval of $85.00 \%<V \leq 100.00 \%$ with completely valid criteria. Practicality obtained an average of 4.659, which is in the interval of $2.50<V \leq 3.25$ with very practical criteria. Effectivenes shows the criteria of $79.83 \%$ berada pada interval $70.00 \%<V \leq 85.00 \%$ dengan kriteria efektif. The effectiveness of the mobile game obtained a significance value of $2.127>2.048$, which means it can improve the learning outcomes of elementary school students in the equality of fractions material. Therefore, the development of mobile games for equality of fraction is concluded to be very valid, very practical, and effective.
\end{abstract}

\section{INTRODUCTION}

Mathematics is an important subject for all students from elementary school to college level. Learning mathematics plays a role in equipping students' competence with the ability to think logically, analytically, systematically, critically, and creatively, as well as the ability to work together. These competencies are needed so that students can have the ability to obtain, manage, and utilize the information for their survival in conditions that are constantly changing, uncertain, and competitive (Fasha et al., 2018). Mathematics is a science with an abstract object of study, so there needs to be reinforcement so that the knowledge gained lasts a long time in students' memory (Parnabhhakti \& Ulfa, 2020). Strengthening knowledge is needed so that concepts can be embedded in students' mindsets and action patterns. Mathematics deals with reasoning based on thought processes (Wahyuningtyas et al., 2021). Educators only rely on the lecture method. Students are not required to find concepts, so many think mathematics lessons are tedious, complex, and difficult to understand. Students also think that mathematics is an unattractive 
subject and has low learning outcomes. This happens because the learning strategies and media used by the teacher are not appropriate (Attard \& Holmes, 2020). Thus, it is necessary to strengthen mathematical knowledge by using appropriate media learning strategies to support student learning outcomes.

Learning outcomes are one form of mathematical development of elementary school students. This form of mathematical development can be seen from changes in the perception of self-concept and selfefficacy towards mathematics (Kaskens et al., 2020). Learning outcomes can also be viewed as a result of one's learning process and students' abilities after experiencing learning. Learning outcomes are used by teachers to be used as a measure or criteria in achieving a learning outcome (Hakim \& Windayana, 2016). Students can improve learning outcomes by finding mathematical concepts because they can re-express what has been communicated to them, use concepts in different situations, and develop some of the consequences of a mathematical concept (Pujiati et al., 2018). Learning outcomes have three domains, namely cognitive, affective and psychomotor. For elementary school students, the cognitive domain plays a vital role in processing conceptual knowledge. The cognitive domain also plays a role in the positive development of other domains and leads to positive mathematical learning achievement (Noorhidawati et al., 2015; Purpura \& Schmitt, 2019).

In learning mathematics, one of the materials considered difficult by students is fractions. Students tend to memorize formulas, but when the character of the questions is changed, they become confused (Tonra, 2016). Elementary school students find it difficult to produce creative solutions to fractional operations problems because their mathematical knowledge is built using memorization (Amir \& Wardana, 2018). The process skills of finding concepts in elementary school students through problem-solving are also relatively low (Zhang \& Rivera, 2021). The cause of the number of students who did not complete the fraction material was that students ignored the learning objectives and conceptual understanding (Ardina et al., 2019). One of the results of the analysis of elementary school students' incompleteness in fractional material is because they focus on procedural mathematical rules without the appropriate depth of conceptual understanding about fractional quantities. It makes many fractional operational rules meaningless (Siegler \& Pyke, 2013). Students who can provide conceptual explanations tend to have a deeper understanding of fractions than students who do not (Geller et al., 2017). If students have a deeper understanding of mathematics and the arguments, they will not make the common core errors that indicate poor performance on standardized tests (Jordan et al., 2013). The results of observations in the fourth grade of SDN Kenongo 1 Tulangan showed that students' mathematics learning in the material of equality of fractions had not used media that was oriented to analytical skills and found patterns of equality of fractions. More than $70 \%$ of students also have incomplete grades in the equality of fractions theme.

Previous studies have carried out various conventional learning media solutions to low learning outcomes in the material of equality of fractions. Students given domino card media treatment have better value fraction learning outcomes than using still image media (Rahaju \& Hartono, 2017). In another similar study, students could use fractional domino cards to train students' fluency, flexibility, and novelty in answering math problems, especially on fractions (Amir \& Wardana, 2018). The use of fractional block teaching aids can improve students' understanding and learning outcomes on common and mixed fractions (Sao et al., 2021). The use of fraction blocks can increase elementary school students' conceptual understanding (Indriani, 2018). Ludo math media has good quality and feasibility in the simple equality of fractions learning process (Azizah \& Fitrianawati, 2020). Thus, it is necessary to have a variety of learning media that utilizes technology in the equality of fractions. However, conventional learning media has limited use only in the classroom, so it does not support student learning needs more flexibly.

The development of technology is increasing day by day. The use of technology and information can make learning activities more interesting, active, and flexible. One of the uses of technological developments is technology media in learning (mobile learning). Media in mobile learning can be interpreted as a facility that provides general electronic information to students or educational content that helps achieve knowledge without considering the location and time to use it (Suartama et al., 2019). With mobile learning, students can access learning media anytime and anywhere without having to wait for an explanation from the teacher first. Mobile learning is prospective and progressive learning to be implemented because it is supported by sophisticated, inexpensive, and reliable communication technology (Astra et al., 2015). Learning using mobile learning brings changes to educators and students in thinking, working, mastery of existing technology, and the ability to adapt and survive. Students can take advantage of the application in building their knowledge of the required material (Efriyanti \& Annas, 2020).

Previous studies have also discussed various variations of mobile technology in elementary schools on the equality of fractions material. The results show that mobile devices can impact students' achievement and numeracy of equality of fractions (Dorris et al., 2021). The Fun Fraction app can teach fractions to students' cognitive strategies, virtual manipulatives, and explicit instructions (Tetzlaff, 2017). Mobile application development can help find equality of fractions, comparisons, and additions in fifth-grade 
elementary school students (Flores et al., 2021). The use of game-based applications can improve students' fractional skills (Yasa, 2020). The application of the fraction for kids is a technology integration that can enable elementary school students to achieve learning targets and fraction differentiation (Simsek \& Can, 2020). Augmented reality applications can improve the equality of fractions for fourth-grade elementary school students (Ivonne et al., 2020). Mobile games make elementary school students understand the concept of fractions more easily (Maharbid et al., 2018). The variation of technology development that has been carried out is based on the perspective that elementary school children who are included in the preoperational or concrete operational period like to learn while playing, so they can practice deepening knowledge (de Ribaupierre, 2015). The results of previous research on mobile game development were limited to increasing knowledge of fractions. However, there has not been an elaboration of understanding and deepening of knowledge on the patterns of equality of fractions. It impacts the low student learning outcomes of the equality of fractions material. This gap needs to be addressed by developing a mobile game technology that can facilitate the learning of equality of fractions by elaborating patterns of equality of fractions. Thus, the purpose of this study is to produce a valid, practical, and effective mobile game for equality of fractions (MoGEF) to improve learning outcomes of equality of fractions more precisely and indepth.

\section{METHOD}

Mobile game for equality of fractions (MoGEF) which was developed using the research and development method, with the stages of analysis, design, development, implementation, and evaluation (ADDIE) (See Figure 1). R\&D is used to produce certain products and test the feasibility of these products (Sugiyono, 2017). The MoGEF was developed using valid, practical, and effective criteria.

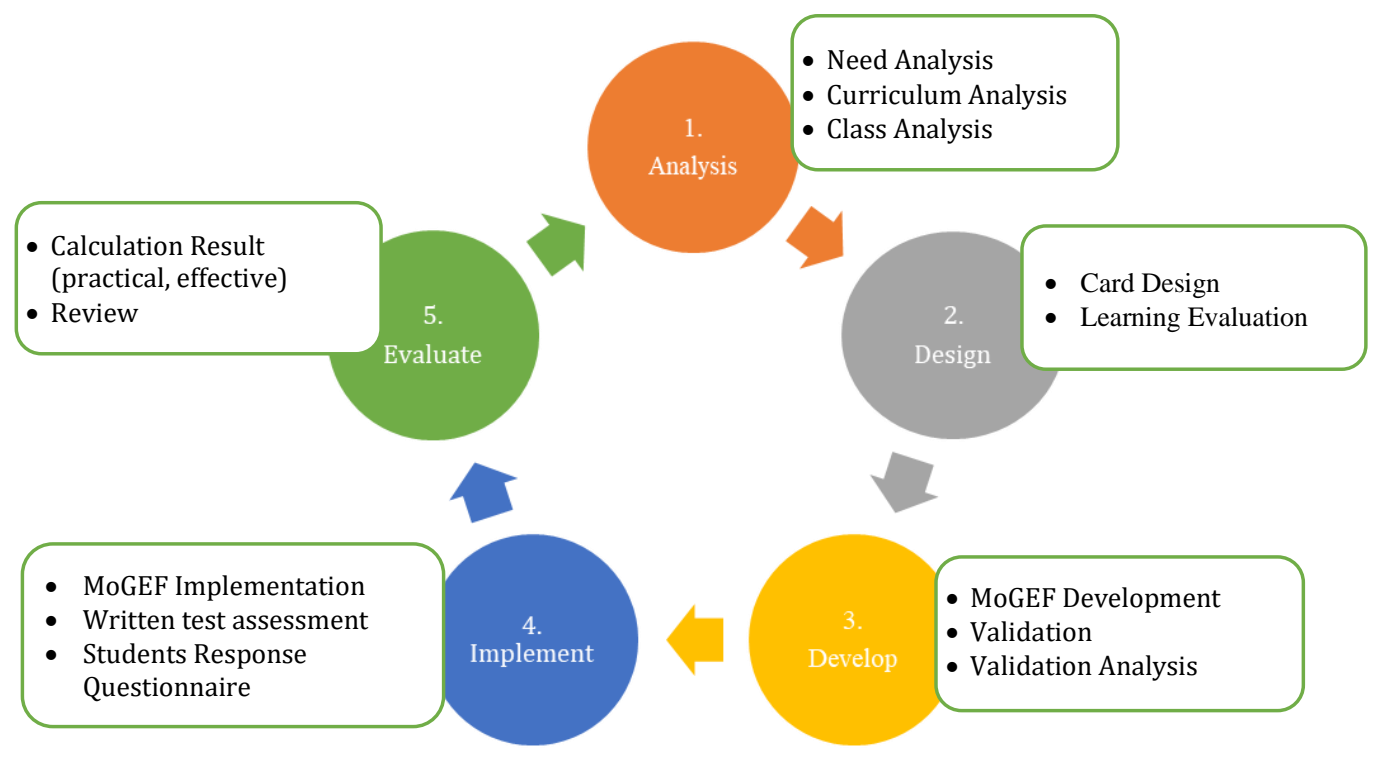

Figure 1. MoGEF Development Process Using ADDIE Model (Adapted From Molenda, 2007)

In the analysis stage, three steps of analysis are carried out on needs, curriculum and classes. Needs analysis is carried out to determine what products need to be developed. Curriculum analysis is carried out by examining Permendikbud Number 65 of 2013, which contains the use of information technology to improve the efficiency and effectiveness of learning. Learning analysis was conducted to identify learning and media used at SDN Kenongo 1 Tulangan. The design stage determines the learning assessment method used based on the results obtained from the analysis stage. The design of the instrument used is a questionnaire of experts (See Table 1), a student response questionnaire (See Table 2), and a test of equality of fractions (See Table 3). MoGEF design considers layout, navigation, content, performance, and usability features (including effectiveness, efficiency, learning ability, error, memory, and cognitive materials). The development stage includes making a product using Adobe Animate CC software and determining the validity of MoGEF. The implementation phase includes the application of MoGEF to students. The evaluation stage is an activity to measure the value of each activity set and whether the product is in accordance with the specifications. The posttest questions used in this study consisted of multiple choice and essays. Multiple choice consists of 10 questions; each question has four possible answers and is worth 4 points with a total 
score of 40. The essay consists of 3 questions, and each question is worth 20 points with a total score of 60 . One mathematics education material expert validates the test questions. Improvements were made to ensure the validity of multiple-choice tests and essays to make the tests valid. The validator suggests that the minimum number of multiple-choice questions is double the number of essay questions.

Table 1. Validator Questionnaire Outline

\begin{tabular}{|c|c|c|c|}
\hline Aspect & Sub Aspect & Indicator & $\begin{array}{c}\text { Number of } \\
\text { Question }\end{array}$ \\
\hline \multirow{4}{*}{ Material } & \multirow{3}{*}{ Material range } & Material suitability & 1 \\
\hline & & Concept charge equality of fractions & 2 \\
\hline & & Game compatibility with the material & 3 \\
\hline & Language quality & Clarity of the language used & 4 \\
\hline \multirow{6}{*}{ Programming } & \multirow{3}{*}{ Media efficiency } & Ease of use of the program & 1 \\
\hline & & Ease of choosing the program menu & 2 \\
\hline & & Ease of starting and ending programs & 3 \\
\hline & \multirow{2}{*}{ Button function } & Easy to understand button structure & 4 \\
\hline & & Button reaction accuracy & 5 \\
\hline & Physical quality & program reliability & 6 \\
\hline \multirow{7}{*}{ Display } & \multirow{5}{*}{ Graphic quality } & Image layout & 1 \\
\hline & & Background selection compatibility & 2 \\
\hline & & Writing clarity & 3 \\
\hline & & Color Match & 4 \\
\hline & & The attractiveness of animated images & 5 \\
\hline & \multirow{2}{*}{ Button Function } & The attractiveness of the button display & 6 \\
\hline & & Button display order & 7 \\
\hline
\end{tabular}

(Adapted From Hidayat et al., 2020)

Table 2. Student Response Questionnaire Outline

\begin{tabular}{clc}
\hline Aspect & \multicolumn{1}{c}{ Indicator } & $\begin{array}{c}\text { Number of } \\
\text { Question }\end{array}$ \\
\hline Effectivity & Understanding equality of fractions & 5 \\
Efficiency & Determine equality of fractionss & 6 \\
Satidfaction & Language used & 3 \\
Failure & Mosy to use MoGEF & 1 \\
Memory & MoGEF card performance & 7 \\
Learning ability & How to use MoGEF & 4 \\
Cognitive Material & Ease of use of MoGEF & 9 \\
\hline & Use of starting and ending MoGEF & 8 \\
& & (Adapted From Parsazadeh et al., 2018)
\end{tabular}

Tabel 3. Outline of Equality of Fractions Assessment Sheet

\begin{tabular}{ll}
\hline \multicolumn{1}{c}{ Indicator } & \multicolumn{1}{c}{ Number } \\
\hline Cognitive & Multiple choice \\
3.1.1 Explaining equality of fractions using MoGEF. & A1, A2, A5 \\
3.1.2 Determine the number of equality of fractions with & Multiple Choice \\
MoGEF & A3, A4, A6, A7, A8, A9, A10 \\
\cline { 2 - 2 } & Essay \\
& B1, B2, B3 \\
\hline
\end{tabular}

The subjects in this study were 29 fourth-grade students of SDN Kenongo 1 Tulangan. One material expert assessed the validity from the mathematics education lecturer and the information technology education lecturer, respectively. Practicality and effectiveness are assessed from the results of 
questionnaires and tests on research subjects. The assessment intervals used to measure the validity and effectiveness of the MoGEF are 85.00\% $<\mathrm{V} \leq 100.00 \%, 70.00 \%<\mathrm{V} \leq 85.00 \%, 50.00 \%<\mathrm{V} \leq 70.00 \%$ and $01.00 \% \leq \mathrm{V} \leq 50.00 \%$ with the criteria of definitely valid/effective, valid/effective, definitely valid/effective and definitely valid/effective. Practicality was converted into $3.25<\mathrm{V} \leq 4.00,2.50<\mathrm{V} \leq$ $3.25,1.75<\mathrm{V} \leq 2.50$ and $1.00 \leq \mathrm{V} \leq 1.75$ with each criterion of definitely practical, practical, less, and not practical (Akbar, 2017).

\section{RESULT AND DISCUSSION}

\section{Result}

MoGEF on equality of fractions was developed with the ADDIE model. The analysis phase shows that students need reinforcement in learning mathematics, especially in the equality of fractions. During the learning process in class, educators only use thematic books and still image media while students cannot play them. As a result, students experience boredom, difficulty understanding, and difficulty finding concepts in the equality of fractions, which leads to poor learning outcomes. One of the strengthening strategies needed is media in the form of mobile technology. The right medium to use is MoGEF. Following the 2013 curriculum used at SDN Kenongo 1 Tulangan, the demands of the 2013 curriculum must utilize information technology to improve the efficiency and effectiveness of learning so that it can support improving student learning outcomes. The design phase focuses on designing the MoGEF to improve student learning outcomes about the equality of fractions. In designing usability guidelines, layout, navigation, content, and performance are highly considered. In addition, the useful features of effectiveness, efficiency, learning ability, errors, memory, and cognitive materials must be contained in the MoGEF. The MoGEF learning framework can be seen in Figure 2. The MoGEF number pattern arrangement was obtained at this stage, namely $\mathrm{C}(\mathrm{n}, \mathrm{r})$, which means the combination of $r$ from $n$, with repetitions allowed. In MoGEF, there are seven different types of fractions, each type has eight numbers, and each card consists of 2 fractions, the top side and the bottom side. Then the possible arrangement is $C(8,2)$, with the allowed repetition of the arrangement being 28 ways.

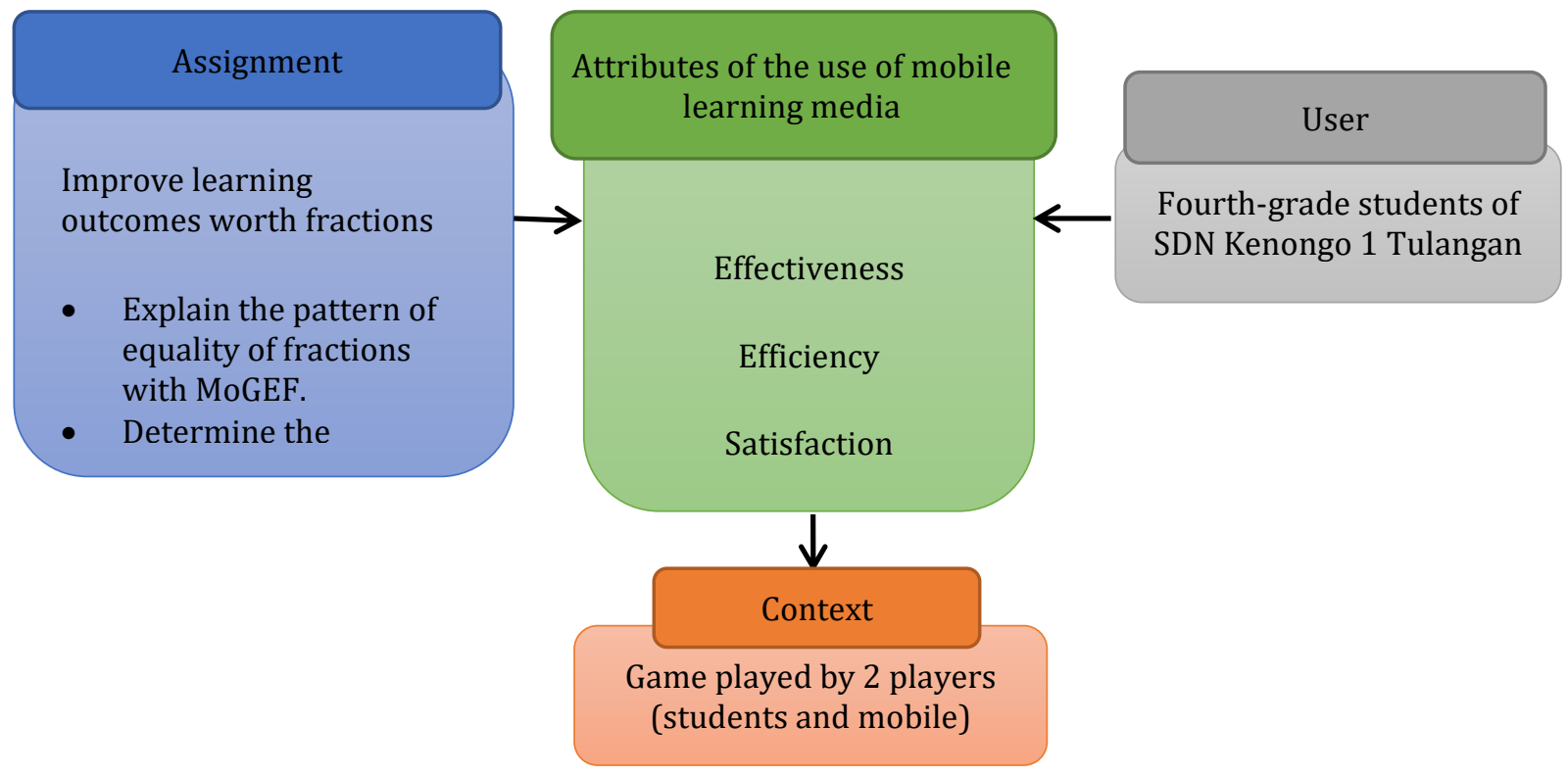

Figure 2. MoGEF Framework 


$$
\begin{array}{ccccccc}
\frac{1 / 2}{1 / 2} & \frac{1 / 2}{1 / 3} & \frac{1 / 2}{1 / 4} & \frac{1 / 2}{1 / 5} & \frac{1 / 2}{1 / 6} & \frac{1 / 2}{2 / 3} & \frac{1 / 2}{2 / 5} \\
& \frac{1 / 3}{1 / 3} & \frac{1 / 3}{1 / 4} & \frac{1 / 3}{1 / 5} & \frac{1 / 3}{1 / 6} & \frac{1 / 3}{2 / 3} & \frac{1 / 3}{2 / 5} \\
& \frac{1 / 4}{1 / 4} & \frac{1 / 4}{1 / 5} & \frac{1 / 4}{1 / 6} & \frac{1 / 4}{2 / 3} & \frac{1 / 4}{2 / 5} \\
& & \frac{1 / 5}{1 / 5} & \frac{1 / 5}{1 / 6} & \frac{1 / 5}{2 / 3} & \frac{1 / 5}{2 / 5} \\
& & & \frac{1 / 6}{1 / 6} & \frac{1 / 6}{2 / 3} & \frac{1 / 6}{2 / 5} \\
& & & & \frac{2 / 3}{2 / 3} & \frac{2 / 3}{2 / 5} \\
& & & & & \frac{2 / 5}{2 / 5}
\end{array}
$$

Figure 3. First Stage Pattern

$$
\begin{array}{ccccccc}
\frac{1 / 2}{1 / 2} & \frac{2 / 4}{7 / 21} & \frac{3 / 6}{6 / 24} & \frac{4 / 8}{5 / 25} & \frac{5 / 10}{4 / 24} & \frac{6 / 12}{6 / 9} & \frac{7 / 14}{4 / 10} \\
\frac{1 / 3}{1 / 3} & \frac{2 / 6}{7 / 28} & \frac{3 / 9}{6 / 30} & \frac{4 / 12}{5 / 30} & \frac{5 / 15}{8 / 12} & \frac{6 / 18}{6 / 15} \\
& \frac{1 / 4}{1 / 4} & \frac{2 / 8}{7 / 35} & \frac{3 / 12}{6 / 36} & \frac{4 / 16}{10 / 15} & \frac{5 / 20}{8 / 20} \\
& & \frac{1 / 5}{1 / 5} & \frac{2 / 10}{7 / 42} & \frac{3 / 15}{12 / 18} & \frac{4 / 20}{10 / 25} \\
& & & \frac{1 / 6}{1 / 6} & \frac{2 / 12}{14 / 21} & \frac{3 / 18}{12 / 30} \\
& & & & \frac{2 / 3}{2 / 3} & \frac{4 / 6}{14 / 35} \\
& & & & & \frac{2 / 5}{2 / 5}
\end{array}
$$

Figure 5. Third Stage Pattern

$$
\begin{array}{ccccccc}
\frac{1 / 2}{1 / 2} & \frac{2 / 4}{1 / 3} & \frac{3 / 6}{1 / 4} & \frac{4 / 8}{1 / 5} & \frac{5 / 10}{1 / 6} & \frac{6 / 12}{2 / 3} & \frac{7 / 14}{2 / 5} \\
\frac{1 / 3}{1 / 3} & \frac{2 / 6}{1 / 4} & \frac{3 / 9}{1 / 5} & \frac{4 / 12}{1 / 6} & \frac{5 / 15}{2 / 3} & \frac{6 / 18}{2 / 5} \\
& \frac{1 / 4}{1 / 4} & \frac{2 / 8}{1 / 5} & \frac{3 / 12}{1 / 6} & \frac{4 / 16}{2 / 3} & \frac{5 / 20}{2 / 5} \\
& & \frac{1 / 5}{1 / 5} & \frac{2 / 10}{1 / 6} & \frac{3 / 15}{2 / 3} & \frac{4 / 20}{2 / 5} \\
& & & \frac{1 / 6}{1 / 6} & \frac{2 / 12}{2 / 3} & \frac{3 / 18}{2 / 5} \\
& & & & \frac{2 / 3}{2 / 3} & \frac{4 / 6}{2 / 5} \\
& & & & & & \frac{2 / 5}{2 / 5}
\end{array}
$$

Figure 4. Second Stage Pattern

$$
\begin{array}{ccccccc}
\frac{1 / 2}{8 / 16} & \frac{2 / 4}{7 / 21} & \frac{3 / 6}{6 / 24} & \frac{4 / 8}{5 / 25} & \frac{5 / 10}{4 / 24} & \frac{6 / 12}{6 / 9} & \frac{7 / 14}{4 / 10} \\
\frac{1 / 3}{8 / 24} & \frac{2 / 6}{7 / 28} & \frac{3 / 9}{6 / 30} & \frac{4 / 12}{5 / 30} & \frac{5 / 15}{8 / 12} & \frac{6 / 18}{6 / 15} \\
& \frac{1 / 4}{8 / 32} & \frac{2 / 8}{7 / 35} & \frac{3 / 12}{6 / 36} & \frac{4 / 16}{10 / 15} & \frac{5 / 20}{8 / 20} \\
& & \frac{1 / 5}{8 / 40} & \frac{2 / 10}{7 / 42} & \frac{3 / 15}{12 / 18} & \frac{4 / 20}{10 / 25} \\
& & & \frac{1 / 6}{8 / 48} & \frac{2 / 12}{14 / 21} & \frac{3 / 18}{12 / 30} \\
& & & & \frac{2 / 3}{16 / 24} & \frac{4 / 6}{14 / 35} \\
& & & & & \frac{2 / 5}{16 / 40}
\end{array}
$$

Figure 6. Fourth Stage Pattern

There are four stages of the arrangement of the cards in Figure 3 to Figure 6. Figure 3 shows the structure of the original domino cards. Figure 4 shows the display on the top side replaced with an equivalent number. Figure 5 shows that the underside structure is replaced with an equivalent number but not used in the third stage number. Figure 6 shows the arrangement of cards in the front row, and the bottom side is replaced with several equal values but has not been used in the third and fourth stage numbers. With the preparation of these stages, the fractional number design is obtained in Figure 7.

$$
\begin{array}{ll}
\text { Type } A \text { is } \frac{1}{2}=\frac{2}{4}=\frac{3}{6}=\frac{4}{8}=\frac{5}{10}=\frac{6}{12}=\frac{7}{14}=\frac{8}{16} & \text { Type } E \text { is } \frac{1}{6}=\frac{2}{12}=\frac{3}{18}=\frac{4}{24}=\frac{5}{30}=\frac{6}{36}=\frac{7}{42}=\frac{8}{48} \\
\text { Type } B \text { is } \frac{1}{3}=\frac{2}{6}=\frac{3}{9}=\frac{4}{12}=\frac{5}{15}=\frac{6}{18}=\frac{7}{21}=\frac{8}{24} & \text { Type } F \text { is } \frac{2}{3}=\frac{4}{6}=\frac{6}{9}=\frac{8}{12}=\frac{10}{15}=\frac{12}{18}=\frac{14}{21}=\frac{16}{24} \\
\text { Type C is } \frac{1}{4}=\frac{2}{8}=\frac{3}{12}=\frac{4}{16}=\frac{5}{20}=\frac{6}{24}=\frac{7}{28}=\frac{8}{32} & \text { Type } G \text { is } \frac{2}{5}=\frac{4}{10}=\frac{6}{15}=\frac{8}{20}=\frac{10}{25}=\frac{12}{30}=\frac{14}{35}=\frac{16}{40}
\end{array}
$$

Figure 7. The Equality of Fractions Pattern Structure

Adobe Animate CC software on a Windows 10 OS type computer, 16 GB RAM, Nvidia GTX 750 Graphics, 500 GB HDD, Intel Core i7 Processor is used for development. This process implements learning media technology in the form of mobile learning games. MoGEF based on mobile learning can be installed at least by Android Jellybean with 1 GB RAM. For content development, MoGEF contains 28 cards in 1 set that can be played by two players, including one student player and the other from a personal computer or mobile system, with players getting five cards, respectively. Before being tested on students, MoGEF was 
validated by experts. The assessment results from material experts obtained $85.04 \%$, which indicated the MoGEF on the criteria was completely valid. The media expert's assessment results obtained $87.08 \%$, which showed the MoGEF on the criteria was completely valid. The input from the media validator is that the card size is slightly increased, and the writing on the card is more clarified. MoGEF has consulted again with media validators and obtained completely valid criteria. The results of the MoGEF development are shown in Figure 8.
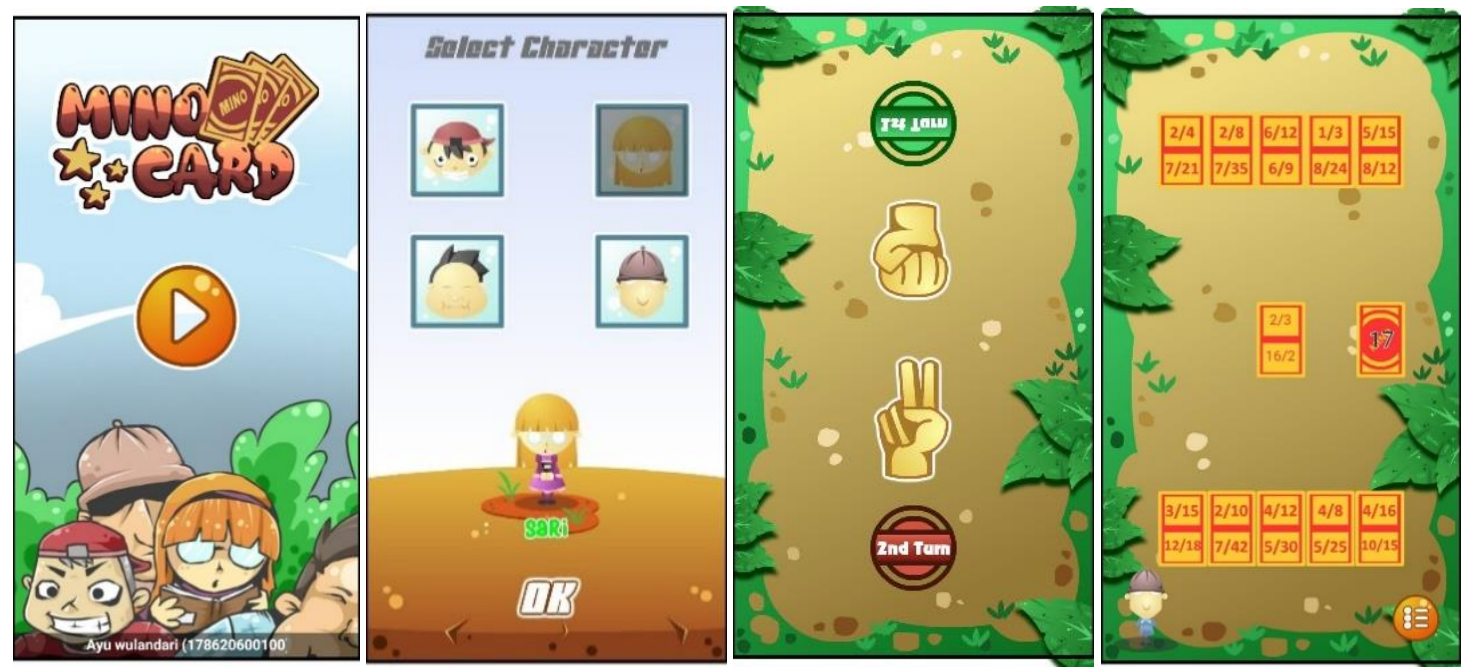

Figure 8. MoGEF Development Display

In Figure 8, the first image shows the initial appearance of the MoGEF, where players can play it by pressing the arrow keys. The second picture shows the display of selecting one of the characters used by the player to play. The third image shows the suit display or random selection that will determine the players' order. The fourth picture shows a display of card designs played by players. The card in the middle is the benchmark card that players will have to find the fractional number equivalent to the card they have. After the MoGEF has been declared very valid, it can be implied to students. Students were given the same treatment; namely, all students played the MoGEF game. The MoGEF game was distributed to students to be downloaded on their respective smartphones. The researcher's first step is to review fractions and especially equality of fractions to determine the knowledge possessed by students. Researchers explain how the MoGEF game works. Students are given 120 minutes to play the MoGEF game. After playing the game, students take an evaluation test to find out the results of learning about the equality of fractions. Students also filled out a response questionnaire to determine student responses to the MoGEF game-the experimental procedure steps in Figure 9.

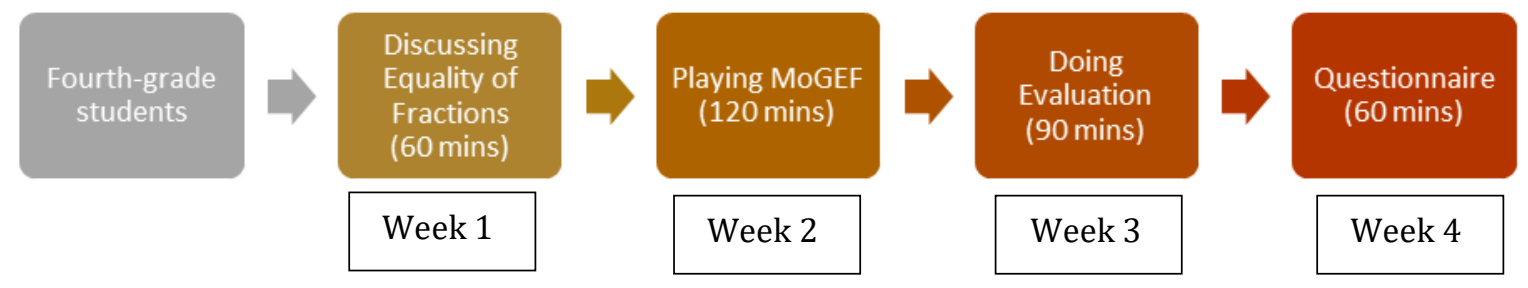

Figure 9. Trial Phase

The researcher calculated the results obtained from filling out the student response questionnaires and evaluation tests at the evaluation stage. Data analysis was performed using SPSS statistical software for windows. Shapiro-Wilk was used to calculate the normality test of the data. The normality test results obtained are 0.324 , so the value is $0.324>0.005$, indicating normal distribution. Furthermore, the data is calculated using the t-test. One sample t-test is a test of the mean or population Means value equal to a certain value $\mu$ o, against the alternative hypothesis, that the $\mu$ population Means value is not equal to $\mu$ o (Nuryani et al., 2017). The results of the student response questionnaires can be seen in Table 4 . The results of the student response questionnaires obtained an average value of 4.659 by obtaining completely practical criteria. Thus, the MoGEF that was developed is completely practical and can be used by students 
to improve learning outcomes towards the equality of fractions. The results of the evaluation test calculations are in Table 5.

Table 4. Students Questionannaire Result

\begin{tabular}{|c|c|c|}
\hline Question & Number & Mean \\
\hline \multicolumn{3}{|l|}{ Effectivity } \\
\hline 1. Through MoGEF, it's easy to understand the equality of fractions & 5 & 4.34 \\
\hline 2. Ease of determining equality of fractions & 6 & 4.31 \\
\hline \multicolumn{3}{|l|}{ Efficiency } \\
\hline 3. The language used is clear & 3 & 4.79 \\
\hline \multicolumn{3}{|l|}{ Satisfaction } \\
\hline 4. Ease of using MoGEF & 1 & 4.62 \\
\hline 5. Interesting image display & 7 & 4.90 \\
\hline \multicolumn{3}{|l|}{ Failures } \\
\hline $\begin{array}{l}\text { 6. When selecting the wrong card, the card will automatically return to its } \\
\text { original place }\end{array}$ & 4 & 4.90 \\
\hline \multicolumn{3}{|l|}{ Memory } \\
\hline 7. It's easy to remember how to use Android-based MoDEL & 9 & 4.66 \\
\hline \multicolumn{3}{|l|}{ Learning ability } \\
\hline 8. It's very easy to learn to use Android-based MoGEF & 8 & 4.69 \\
\hline 9. Button instructions make it easy to operate MoGEF & 10 & 4.69 \\
\hline \multicolumn{3}{|l|}{ Cognitive Material } \\
\hline 10. Ease in the beginning and ending MoGEF & 2 & 4.69 \\
\hline Mean Total & & 46.59 \\
\hline Mean total (\%) & & 4.659 \\
\hline
\end{tabular}

Table 5. Evaluation Test Result

\begin{tabular}{lccc}
\hline & N & Mean & Std. Deviation \\
\hline Multiple-choice & 29 & 32.14 & 5.705 \\
Essay & 29 & 47.69 & 12.145 \\
\hline Mean Total (\%) & & $\mathbf{7 9 . 8 3}$ & \\
\hline
\end{tabular}

Table 5 shows that the evaluation test results obtained an average value of $79.83 \%$ by obtaining effective criteria. Calculation of t-count with t-table obtained $2.127>2.048$, which indicates Ho is rejected because t-count is more significant than t-table, so it can be concluded that students increase learning outcomes on equality of fractions. In addition to data calculations, researchers will conduct a review to determine the feasibility of the product developed, namely MoGEF. The needs analysis stage concluded that students needed strengthening strategies in learning, namely media in mobile technology. So far, teachers only used thematic books and still image media, causing boredom, difficulty understanding, and inability to find the concept of equality of fractions. The design stage was carried out by designing a questionnaire instrument, testing, and compiling the MoGEF card. In developing the media, the researcher also determines the layout, navigation, content, and performance. The development stage produces 28 cards in 1 set. The material expert's assessment results obtained $85.04 \%$, which indicated the MoGEF on the criteria was very valid. The media expert's assessment results obtained $87.08 \%$, which showed the MoGEF on the criteria was completely valid. The results of the student response questionnaires obtained an average value of 4.659 by obtaining completely practical criteria. The results of the evaluation test obtained an average value of $79.83 \%$ by obtaining effective criteria. The results of data analysis show that there is an influence on the use of MoGEF. So it can be concluded that the Mobile game for equality of fractions (MoGEF) is completely valid, practical, and effective for students to improve learning outcomes on equality of fractions material.

\section{Discussion}

The study results stated that MoGEF was completely valid, practical, and effective in improving student learning outcomes in the equality of fractions. The results of this study can help teachers improve learning outcomes on students' equality of fractions. Previously ( Amir \& Wardana, 2018; Baiquni, 2016; Rahaju \& Hartono, 2017) used learning media that is played physically only. The previous literature does not consider its practicality (student responses to learning media) and its effectiveness. Its implementation is inseparable from the development steps taken. At the analysis stage, learning mathematics requires reinforcement and the right strategy. The need in the era of 4.0 is mobile learning per the curriculum used 
at SDN Kenongo 1 Tulangan, namely the 2013 curriculum, which requires technology in the learning process. That way, students can be given reinforcement by using mobile learning media to improve student learning outcomes. Mobile learning media that can improve learning outcomes of the equality of fractions is MoGEF. Previous research stated that smart domino cards could improve fractions learning achievement (Rahaju \& Hartono, 2017). A similar study also stated that using domino card media can improve students' creative thinking skills (Amir \& Wardana, 2018). After obtaining the results of the analysis, the MoGEF design stage was held. Media design refers to the suitability of usability features, including effectiveness, efficiency, learning ability, error, memory, and cognitive materials (Parsazadeh et al., 2018). It aims to improve the learning outcomes of the equality of fractions. In addition, layout, navigation, content, and performance should also be considered in media design. In the preparation of the MoGEF, a card number pattern design was obtained with one card containing two different fractions. There are seven different types of fractions, and each type has eight equality of fractions, so 28 cards are accepted in a set.

MoGEF media was created using Adobe Animate CC software and produced mobile learning-based media at the development stage. Adobe Animate CC is a software that can produce smartphone output with ActionScript that supports and includes the most popular web animation technologies (Chun,2017). Previous research stated that mobile learning is prospective and progressive learning to be implemented because it is supported by sophisticated, inexpensive, and reliable communication technology (Astra et al., 2015). MoGEF can be played by two players, one student player and the other from a personal computer or mobile system. The validation was carried out at this stage by involving two experts (one material expert, namely a mathematics education lecturer, and one media expert, namely an information technology education lecturer). The results of the material expert assessment obtained $85.04 \%$, which showed the MoGEF on completely valid criteria. The results of the media expert assessment obtained 87.08\%, which shows MoGEF on completely valid criteria. In the implementation phase, MoGEF was tested on fourth-grade students of SDN Kenongo 1 Tulangan with 29 students. The MoGEF link is shared with students, and students can install it on their respective smartphones. When playing the MoGEF, the students seemed excited and happy. There is a significant influence between the use of the play learning method on student learning outcomes for the subject matter of fractions (Baiquni, 2016). After students play the game, students evaluate to measure the learning outcomes of equality of fractions obtained by students. Learning outcomes are used by teachers to be used as measures or criteria in achieving an educational goal, and learning outcomes can be seen after students experience learning (Hakim \& Windayana, 2016). Students also filled out a response questionnaire to find out the student's responses to the developed MoGEF game.

The evaluation phase includes feedback on the development that has been carried out, namely the MoGEF. Research and development need to consider quality criteria (Nieveen, 2015). The quality of product feasibility is tested with three criteria of validity, practicality, and effectiveness. If the MoGEF meets these criteria, there is no need for revision of the developed media. The calculation of data from the student response questionnaire shows an average value of 4.659 by obtaining completely practical criteria. The results of the evaluation test obtained an average value of $79.83 \%$ by getting effective criteria. This study indicates that students experience increased learning outcomes in fractions' equality after playing the MoGEF game. It can be said that the MoGEF mobile learning game effectively improves learning outcomes (Fatoni \& Rosalina, 2021). The effectiveness of mobile learning can increase interest in learning and student learning outcomes (Rahmat et al., 2019). The effectiveness of using Android-based mobile learning media on learning outcomes is very good (Arsyad \& Lestari, 2020). The results of previous studies stated that fractional domino card media could improve students' creative thinking skills (Amir \& Wardana, 2018). The learning outcomes of students who play smart dominoes show an increase in fraction material (Rahaju \& Hartono, 2017). Similar research states that the fractional domino learning media is very feasible to use in terms of media and material, responses, and students' understanding after using the fractional domino learning media (Setiawan et al., 2020). Learning media for Maca (fractional material) applications is oriented towards Ausubel Learning Theory with mathematical content Students become more active and creative to facilitate the learning process (Rasvani \& Wulandari, 2021).

The final result of this research is the MoGEF product. The development of MoGEF is carried out with appropriate standards for students with completely valid, practical, and effective criteria. However, the development of MoGEF only analyzes the needs of one school, so the needs of other schools are not known. The equality of fractions material contained in MoGEF is only in the form of ordinary fractions. This study implies that MoGEF can be used as a solution for teachers and students in learning mathematics to train and improve the pattern of equality of fractions to improve student learning outcomes. The reason is that MoGEF can facilitate the study of equality of fractions by elaborating patterns of equality of fractions, and its use has no time or place limits. The results of this study can be used as a reference for other researchers who want to develop similar mobile games. It is recommended for further researchers to conduct a needs analysis in several schools to develop mobile technology that is carried out and presents 
various versions of fractional forms so that they can support students in training and improving patterns in the fractions and student learning outcomes..

\section{CONCLUSION}

The MoGEF development carried out is feasible to apply to students by obtaining valid, practical, and effective criteria. Understanding and deepening knowledge of patterns of equality of fractions are found in MoGEF to facilitate students in learning equality of fractions through these patterns. MoGEF can be used as a solution for teachers when learning mathematics on equality of fractions to improve understanding of equality of fractions patterns. MoGEF can significantly help students to get learning outcomes on equality of fractions material significantly.

\section{REFERENCES}

Akbar, S. (2017). Instrumen perangkat pembelajaran. Bandung : PT Remaja Rosdakarya.

Amir, M. F., \& Wardana, M. D. K. (2018). Pengembangan domino pecahan berbasis open ended untuk meningkatkan kemampuan berpikir kreatif siswa sd. AKSIOMA: Jurnal Program Studi Pendidikan Matematika, 6(2), 178. https://doi.org/10.24127/ajpm.v6i2.1015.

Ardina, F. N., Fajriyah, K., \& Budiman, M. A. (2019). Keefektifan model realistic mathematic education berbantu media manipulatif terhadap hasil belajar matematika pada materi operasi pecahan. Jurnal Pedagogi Dan Pembelajaran, 2(2), 151. https://doi.org/10.23887/jp2.v2i2.17902.

Arsyad, M. N., \& Lestari, D. E. G. (2020). Efektifitas penggunaan media mobile learning berbasis android terhadap hasil belajar mahasiswa ikip budi utomo malang. Agastya: Jurnal Sejarah Dan Pembelajarannya, 10(1), 89. https://doi.org/10.25273/ajsp.v10i1.5072.

Astra, I. M., Nasbey, H., \& Nugraha, A. (2015). Development of an android application in the form of a simulation lab as learning media for senior high school students. Eurasia Journal of Mathematics, Science and Technology Education, 1081-1088. https: //doi.org/10.12973/eurasia.2015.1376a.

Attard, C., \& Holmes, K. (2020). "It gives you that sense of hope": An exploration of technology use to mediate student engagement with mathematics. Heliyon, 6(1), e02945. https://doi.org/10.1016/j.heliyon.2019.e02945.

Azizah, A. N, Fitrianawati, M. (2020). Pengembangan media ludo math pada materi pecahan sederhana bagi peserta didik kelas iii sekolah dasar. https://doi.org/10.24176/wasis.v1i1.4709.

Baiquni, I. (2016). Penggunaan media ular tangga terhadap hasil belajar matematika. Jkpm, 01(02), 193203. https://doi.org/10.30998/jkpm.v1i2.1187.

Chun, R. (2017). Adobe animate CC. Amerika : Peachit

de Ribaupierre, A. (2015). Piaget's Theory of Cognitive Development. International Encyclopedia of the Social \& Behavioral Sciences: Second Edition, 18, 120-124. https://doi.org/10.1016/B978-0-08097086-8.23093-6.

Dorris, C., Winter, K., O’Hare, L., \& Lwoga, E. T. (2021). Protokol: A systematic review of mobile device use in the primary school classroom and its impact on pupil literacy and numeracy attainment. Campbell Systematic Reviews, 17(2). https://doi.org/10.1002/cl2.1155.

Efriyanti, L., Annas, F. (2020). Aplikasi mobile learning sebagai sarana pembelajaranabad 21 pada era revolusi industri 4.0.5(1). https://doi.org/10.30983/educative.v5i1.3132.

Fasha, A., Johar, R., \& Ikhsan, M. (2018). Peningkatan kemampuan pemecahan masalah dan berpikir kritis matematis siswa melalui pendekatan metakognitif. Jurnal Didaktik Matematika, 5(2), 53-64. https://doi.org/10.24815/jdm.v5i2.11995.

Fatoni, P., Rosalina, M. (2021). Efektifitas penggunaan games edukasi untuk meningkatkan kemampuan dan hasil belajar siswa dengan aplikasi mobile learning pada mata kuliah computer programming. 13(1), 80-96. https://doi.org/10.37424/informasi.v13i1.74.

Flores-Velazquez, S., Jaimez-González, C. R., \& García-Mendoza, B. (2021). Mobile application to practice fractions through games for primary school children. Universal Journal of Educational Research, 9(1), 76-84. https://doi.org/10.13189/ujer.2021.090109.

Geller, E. H., Son, J. Y., \& Stigler, J. W. (2017). Conceptual explanations and understanding fraction $\begin{array}{llll}\text { comparisons. Learning } \quad \text { Instruction, } & \text { 122-129. }\end{array}$ https: //doi.org/10.1016/j.learninstruc.2017.05.006.

Hakim, A. R., \& Windayana, H. (2016). Pengaruh penggunaan multimedia interaktif dalam pembelajaran matematika untuk meningkatkan hasil belajar siswa sd. EduHumaniora / Jurnal Pendidikan Dasar Kampus Cibiru, 4(2). https://doi.org/10.17509/eh.v4i2.2827. 
Hidayat, W., Patmanthara, S., Setiani, A., Sutikno, T. A., \& Sutadji, E. (2020). Pelatihan pengembangan mobile game edukasi untuk guru smk bidang teknologi komputer dan informatika kota malang. Jurnal Karinov, 3(1). https://doi.org/10.17977/um045v3i1p31-36.

Indriani, A. (2018). Penggunaan blok pecahan pada materi pecahan sekolah dasar. JIPMat, 3(1), 11-16. https://doi.org/10.26877/jipmat.v3i1.2418.

Ivonne, H. P. A., Alberto, M. P. M., \& Guadalupe, C. F. R. (2020). Augmented reality application for teaching basic operations with fractions of the same denominator. Journal of Computer Science, 16(7), 10421062. https://doi.org/10.3844/jcssp.2020.1042.1062.

Jordan, N. C., Hansen, N., Fuchs, L. S., Siegler, R. S., Gersten, R., \& Micklos, D. (2013). Journal of experimental child developmental predictors of fraction concepts and procedures. Journal of Experimental Child Psychology, 116(1), 45-58. https://doi.org/10.1016/j.jecp.2013.02.001.

Kaskens, J., Segers, E., Goei, S. L., van Luit, J. E. H., \& Verhoeven, L. (2020). Impact of Children's math selfconcept, math self-efficacy, math anxiety, and teacher competencies on math development. Teaching and Teacher Education, 94, 103096. https://doi.org/10.1016/j.tate.2020.103096.

Maharbid, D. A., Gumala, Y., Jupri, A., Herman, T. (2018). Mobile game design for understanding fractional conception in elementary school. International, 3, 836-841. http://science.conference.upi.edu/proceeding/index.php/ICMScE/article/view/61.

Molenda, M. (2007). In search of the elusive addie model. Performance Improvement, 46(9), 9-16. https://doi.org/10.1002/pfi.

Noorhidawati, A., Ghalebandi, S. G., \& Siti Hajar, R. (2015). How do young children engage with mobile apps? Cognitive, psychomotor, and affective perspective. Computers and Education, 87, 385-395. https://doi.org/10.1016/j.compedu.2015.07.005.

Nuryani, Astuti, T. D., Utami. E. S., Budiantoro, M. (2017). Dasar - dasar statistik penelitian. Yogyakarta : Sibuku Media

Parnabhhakti, L., \& Ulfa, M. (2020). Perkembangan matematika dalam filsafat. 1(1), 11-14. https://doi.org/10.33365/ji-mr.v1i1.154.

Parsazadeh, N., Ali, R., \& Rezaei, M. (2018). A framework for cooperative and interactive mobile learning to improve online information evaluation skills. Computers and Education, 120(May 2017), 75-89. https://doi.org/10.1016/j.compedu.2018.01.010.

Pujiati, P., Kanzunnudin, M., \& Wanabuliandari, S. (2018). Analisis pemahaman konsep matematis siswa kelas IV sdn 3 gemulung pada materi pecahan. ANARGYA: Jurnal Ilmiah Pendidikan Matematika, 1(1), 37-41. https://doi.org/10.24176/anargya.v1i1.2278.

Purpura, D. J., \& Schmitt, S. A. (2019). Cross-domain development of early academic and cognitive skills. Early Childhood Research Quarterly, 46, 1-4. https://doi.org/10.1016/j.ecresq.2018.10.009.

Rahaju, R., \& Hartono, S. R. (2017). Pembelajaran operasi pecahan dengan kartu domino pintar. JIPMat, 1(2), 173-181. https://doi.org/10.26877/jipmat.v1i2.1244.

Rahmat, R. F., Mursyida, L., Rizal, F., Krismadinata, K., \& Yunus, Y. (2019). Pengembangan media pembelajaran berbasis mobile learning pada mata pelajaran simulasi digital. Jurnal Inovasi Teknologi Pendidikan, 6(2), 116-126. https://doi.org/10.21831/jitp.v6i2.27414.

Rasvani, N. L. A., \& Wulandari, I. G. A. (2021). Pengembangan media pembelajaran aplikasi maca ( materi pecahan ) berorientasi teori belajar ausubel muatan matematika. Mimbar PGSD Undiksha, 9(1), 7481. https://doi.org/10.23887/jjpgsd.v9i1.32032.

Sao, S., Mei, A., Ningsih, N., Mei, M. F., Wondo, M. T. S., Seto, S. B., Naja, F. Y., Meke, K. D. P., \& Manda, G. S. (2021). Bimbingan belajar di rumah menggunakan alat peraga blok pecahan pada masa pandemi covid 19. Mitra Mahajana: Jurnal Pengabdian Masyarakat, 2(2), 193-201. https://doi.org/10.37478/mahajana.v2i2.1031.

Setiawan, Y. U., Asih, I., Yandari, V., \& Pamungkas, A. A. N. S. (2020). Development of fraction domino card as mathematics learning media in elementary school class IV. 12(01), 1-12. https://doi.org/10.30998/formatif.v11i1.8158.

Siegler, R. S., \& Pyke, A. A. (2013). Developmental and individual differences in understanding of fractions. Developmental Psychology, 49(10), 1994-2004. https://doi.org/10.1037/a0031200.

Simsek, I., \& Can, T. (2020). Using tablets for technology integration in classroom differentiation. The Role of Technology in Education, 1-20. https://doi.org/10.5772/intechopen.85713.

Suartama, I. K., Setyosari, P., Sulthoni, \& Ulfa, S. (2019). Development of an instructional design model for mobile blended learning in higher education. International Journal of Emerging Technologies in Learning, 14(16), 4-22. https://doi.org/10.3991/ijet.v14i16.10633.

Sugiyono. (2017). Metode penelitian pendidikan pendekatan kuantitatif, kualitatif, dan $R$ \& D. Bandung : Alfabeta.

Tetzlaff, D. M. (2017). Using mobile technology to increase the math achievement and engagement of 
students with disabilities. Dissertation Abstracts International Section A: Humanities and Social Sciences, 3-A(E), No-Specified. https://doi.org/10.34917/11156827.

Tonra, W. S. (2016). Pembelajaran number sense untuk meningkatkan hasil belajar siswa sekolah dasar pada materi pecahan. 109-116. https://doi.org/10.33387/dpi.v5i2.233.

Wahyuningtyas, S., \& Leonard, L. (2021). Developing Matmino (domino mathematics) learning media in grade 7 algebra material. Formatif: Jurnal Ilmiah, 11(148), 1-14. https://doi.org/10.30998/formatif.v11i1.8158.

Yasa, A. D. (2020). Pengembangan e-evaluation berbasis aplikasi hot potatoes untuk siswa kelas V sekolah dasar. Jurnal Ilmiah Sekolah Dasar, 4(1), 26. https://doi.org/10.23887/jisd.v4i1.23987.

Zhang, D., \& Rivera, F. D. (2021). Predetermined accommodations with a standardized testing protocol: Examining two accommodation supports for developing fraction thinking in students with mathematical difficulties. Journal of Mathematical Behavior, 62(January), 100861. https://doi.org/10.1016/j.jmathb.2021.100861. 